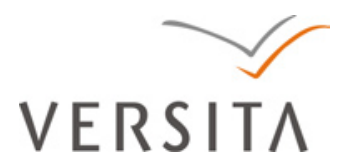

Folia Oeconomica Stetinensia

DOI: $10.2478 /$ foli-2013-0010

\section{us WNIEI}

Wydzial Nauk Ekonomicznych i Zarządzania Uniwersytetu Szczecińskiego

\title{
THE IMPACT OF THE JANUARY EFFECT ON THE IPO UNDERPRICING IN POLAND
}

\author{
Adrian Wołoszyn, Ph.D. \\ Szczecin University \\ Faculty of Economics and Management \\ Mickiewicza 64, 71-101 Szczecin, Poland \\ adrian.woloszyn@gmail.com
}

Prof. Dariusz Zarzecki

Szczecin University

Faculty of Economics and Management

Mickiewicza 64, 71-101 Szczecin, Poland

e-mail:dariusz.zarzecki@wneiz.pl

\begin{abstract}
We examine the initial public offering (IPO) underpricing phenomenon in Poland using data from the Warsaw Stock Exchange (the main market). In the article we survey historical average IPO underpricing in Europe and outside Europe. We discuss the determinants of the IPO underpricing which is based on asymmetry of information, ownership and control, institutional explanations and behavioural explanations. We discuss the calendar effect and we examine the influence of the January effect on the IPO underpricing. On the Warsaw Stock Exchange in 2005-2011, the IPO underpricing was bigger for companies that debuted in January than for companies that debuted in other months. The empirical results are not statistically significant.
\end{abstract}

Keywords: IPO Underpricing, Stock Exchange, Warsaw Stock Exchange, January effect.

JEL classification: G11, G14, G15. 


\section{Introduction}

Initial public offering is one of the methods of raising capital available to companies. The first listing is, however, related to one of the most widely discussed anomalies in the capital market, i.e. the difference between the offering price and the first-day price. The offering price is estimated in advance for the purpose of the public offering; it is a price at which shares are offered in the primary market. The first-day price, on the other hand, is the market price recorded on the debut day. This price can be set as either an opening or closing price. If the offering price is higher than the first-day price, the stock is considered to be overpriced, if the opposite is true, the stock is considered to be underpriced. Regardless of the period, the IPO underpricing is a much more common phenomenon than overpricing. The IPO underpricing is a problem faced by emerging and developed markets. In the literature on the subject both IPO underpricing and overpricing are measured with the initial return, also known as the first-day return, which is estimated as the ratio of the difference between the first-day price and the offering price to the first-day price. From the financial point of view, the underpricing effect is expressed in the amount of the "money left on the table". Offering underpriced stock is related to opportunity costs as the "money left on the table" is an indirect cost of an IPO".

The next part of the paper provides a literature overview, presents historical results of studies into IPO underpricing both in Poland and across the world, and offers a short description of the Warsaw Stock Exchange. In the second part of the paper the January effect is discussed; the explanations of the underpricing effect are also summarised and classified. Next, in part three, the main hypothesis as well as the data and methodology used in the study are presented. In part four the results of the study into IPO underpricing in the WSE are discussed and the hypothesis on the impact of the January effect on underpricing is verified. The last part of the paper summarises the findings and conclusions.

\section{IPO underpricing across the world and in Poland}

In 1963 the US Securities and Exchange Commission began investigating the underpricing phenomenon in the US market ${ }^{2}$. The Commission analysed 1,671 IPOs in the US stock exchange which took place between 1959 and 1961. The results revealed a positive average initial return on investment in the shares offered in the market for the first time. In $79 \%$ of IPOs the first-day price was higher than the offering price and the average underpricing exceeded $20 \%$.

In 1967 a similar study into the underpricing phenomenon was carried out for the London Stock Exchange ${ }^{3}$. Here, too, the results provided evidence supporting the occurrence of the 
underpricing phenomenon among companies offering their shares in the market for the first time, and revealed an average underpricing of $17.2 \%$ in the sample. In both the UK and the US studies the underpricing phenomenon was measured with the initial return on IPO based on the closing price. The employment of the closing price was related to an easier access to relevant data for that period. IPO underpricing was also identified in many other studies carried out for a number of other markets for various periods. The average IPO underpricing for companies entering the capital market was estimated at approx. $36.5 \%$, the actual scale of the phenomenon varied with the country and period of analysis. The results of studies into IPO underpricing inside Europe are presented in Table 1 and outside Europe in Table 2.

Table 1. Average initial return in Europe

\begin{tabular}{|c|c|c|c|c|}
\hline Country & Time period & Sample size & $\begin{array}{l}\text { Average initial } \\
\text { return }(\%)\end{array}$ & Reserchers \\
\hline Austria & $1971-2010$ & 102 & 6.50 & Aussenegg; Ritter \\
\hline Belgium & 1984-2006 & 114 & 13.50 & $\begin{array}{l}\text { Rogiers, Manigart \& Ooghe; Manigart DuMortier; } \\
\text { Ritter }\end{array}$ \\
\hline Bulgaria & 2004-2007 & 9 & 36.50 & Nikolov \\
\hline Cyprus & 1999-2002 & 51 & 23.70 & Gounopoulos, Nounis and Stylianides \\
\hline Denmark & 1984-2006 & 145 & 8.10 & Jakobsen \& Sorensen; Ritter \\
\hline Finland & $1971-2006$ & 162 & 17.20 & Keloharju \\
\hline France & $1983-2010$ & 697 & 10.50 & $\begin{array}{l}\text { Husson \& Jacquillat; Leleux \& Muzyka; Paliard } \\
\text { \& Belletante; Derrien \& Womack; Chahine; Ritter; } \\
\text { Vismara }\end{array}$ \\
\hline Germany & $1978-2010$ & 721 & 24.70 & Ljungqvist; Rocholl: Ritter; Vismara \\
\hline Greece & 1976-2007 & 373 & 50.90 & $\begin{array}{l}\text { Nounis, Kazantzis \& Thomas; Thomadakis, } \\
\text { Gounopoulos \& Nounis }\end{array}$ \\
\hline Hungary & 1991-1998 & 33 & 15.10 & Lyn and Zychowicz \\
\hline Ireland & 1999-2006 & 31 & 23.70 & Ritter \\
\hline Italy & 1985-2009 & 273 & 16.40 & $\begin{array}{l}\text { Arosio, Giudici \& Paleari Cassia, Paleari \& Redondi; } \\
\text { Vismara }\end{array}$ \\
\hline Netherlands & 1982-2006 & 181 & 10.20 & $\begin{array}{l}\text { Wessels; Eijgenhuijsen \& Buijs Jenkinson, } \\
\text { Ljungqvist, \& Wilhelm; Ritter }\end{array}$ \\
\hline Norway & 1984-2006 & 153 & 9.60 & Emilsen, Pedersen \& Saettem; Liden; Ritter \\
\hline Poland & $1991-2006$ & 224 & 25.30 & Jelic \& Briston; Ritter \\
\hline Portugal & 1992-2006 & 28 & 11.60 & Almeida \& Duque; Ritter \\
\hline Russia & 1999-2006 & 40 & 4.20 & Ritter \\
\hline Spain & $1986-2006$ & 128 & 10.90 & Ansotegui \& Fabregat; Alvarez Otera \\
\hline Sweden & $1980-2006$ & 406 & 27.30 & Rydqvist; Schuster; Simonov; Ritter \\
\hline Switzerland & $1983-2008$ & 159 & 28.00 & Kunz,Drobetz, Kammermann \& Walchli; Ritter \\
\hline Turkey & 1990-2008 & 315 & 10.60 & Kiymaz; Durukan; Ince; Kucukkocaoglu \\
\hline U.K. & $1959-2010$ & 4267 & 16.20 & Dimson; Levis \\
\hline
\end{tabular}

Source: own study based on: Loughran, Ritter, Rydqvist (2010); Aminul, Ruhani, Zamri (2010), pp. 36-46; Gounopoulos, Nounis, Stylianides (2007), pp. 1-25. 
Table 2. Average initial return outside Europe

\begin{tabular}{|c|c|c|c|c|}
\hline Country & $\begin{array}{l}\text { Time } \\
\text { period }\end{array}$ & $\begin{array}{l}\text { Sample } \\
\text { size }\end{array}$ & $\begin{array}{l}\text { Average initial } \\
\text { return }(\%)\end{array}$ & Reserchers \\
\hline Argentina & 1991-1994 & 20 & 4.4 & Eijgenhuijsen \& van der Valk \\
\hline Australia & $1976-2010$ & 1462 & 22.8 & Lee, Taylor \& Walter; Woo; Pham; Ritter \\
\hline Bangladesh & 1994-2001 & 113 & 285.2 & Hoque and Musa \\
\hline Brazil & $1979-2011$ & 275 & 33.1 & Aggarwal, Leal \& Hernandez; Saito; Ushisima \\
\hline Canada & $1971-2010$ & 696 & 6.7 & $\begin{array}{l}\text { Jog \& Riding; Jog \& Srivastava; Kryzanowski, Lazrak } \\
\text { \& Rakita; Ritter }\end{array}$ \\
\hline Chile & $1982-2006$ & 65 & 8.4 & Aggarwal, Leal \& Hernandez; Celis \& Maturana; Ritter \\
\hline China & 1990-2010 & 2102 & 137.4 & Chen, Choi, \& Jiang; Jia \& Zhang \\
\hline Egypt & $1990-2000$ & 53 & 8.4 & Omran \\
\hline Hong Kong & $1980-2010$ & 1259 & 15.4 & $\begin{array}{l}\text { McGuinness; Zhao \& Wu; Ljungqvist \& Yu; Fung, Gul, } \\
\text { and Radhakrishnan; Ritter }\end{array}$ \\
\hline India & 1992-2007 & 2811 & 92.7 & Marisetty and Subrahmanyam \\
\hline Indonesia & $1990-2010$ & 361 & 26.3 & Suherman \\
\hline Iran & $1991-2004$ & 279 & 22.4 & Bagherzadeh \\
\hline Israel & 1990-2006 & 348 & 13.8 & Kandel, Sarig \& Wohl; Amihud \& Hauser; Ritter \\
\hline Japan & 1970-2010 & 3100 & 40.4 & $\begin{array}{l}\text { Fukuda; Dawson \& Hiraki; Hebner \& Hiraki; Pettway } \\
\text { \& Kaneko; Hamao, Packer, \& Ritter; Kaneko \& Pettway }\end{array}$ \\
\hline Jordan & 1999-2008 & 53 & 149.0 & Marmar \\
\hline Korea & 1980-2010 & 1593 & 61.6 & $\begin{array}{l}\text { Dhatt, Kim \& Lim; Ihm; Choi \& Heo; Mosharian \& Ng; } \\
\text { Cho; Joh; Ritter }\end{array}$ \\
\hline Malaysia & 1980-1998 & 401 & 104.1 & Isa \& Yong \\
\hline Mexico & $1987-1994$ & 88 & 15.9 & $\begin{array}{l}\text { Aggarwal, Leal \& Hernandez; Eijgenhuijsen } \\
\text { \& van der Valk }\end{array}$ \\
\hline New Zealand & 1979-2006 & 214 & 20.3 & Vos \& Cheung; Camp \& Munro; Ritter \\
\hline Nigeria & 1989-2006 & 114 & 12.7 & Ikoku; Achua \\
\hline Philippines & $1987-2006$ & 123 & 21.2 & Sullivan \& Unite; Ritter \\
\hline Saudi Arabia & $2003-2010$ & 76 & 264.5 & Al-Anazi, Forster, \& Liu \\
\hline Singapore & 1973-2008 & 519 & 27.4 & Lee, Taylor \& Walter; Dawson; Ritter \\
\hline South Africa & 1980-2007 & 285 & 18.0 & Page \& Reyneke; Ali, Subrahmanyam \& Gleason; Ritter \\
\hline Sri Lanka & $1987-2008$ & 105 & 33.5 & Samarakoon \\
\hline Taiwan & 1980-2006 & 1312 & 37.2 & Chen \\
\hline Thailand & $1987-2007$ & 459 & 46.7 & $\begin{array}{l}\text { Wethyavivorn \& Koo-smith; Lonkani \& Tirapat; } \\
\text { Ekkayokkaya and Pengniti }\end{array}$ \\
\hline U.S. & 1960-2011 & 12246 & 16.8 & Ibbotson, Sindelar \& Ritter; Ritter \\
\hline
\end{tabular}

Source: own study based on: Loughran, Ritter, Rydqvist (2010); Aminul, Ruhani, Zamri (2010), pp. 36-46; Gounopoulos, Nounis, Stylianides (2007), pp. 1-25.

The results of 50 independent surveys conducted across the world did not reveal the IPO overpricing in any country. The lowest underpricing was reported in Russia $-4.2 \%$, and the highest - in Bangladesh, where it reached 285.2\%.

Underpricing in the WSE in Poland in the years 1991-1998, according to the study by Jelic and Briston, was estimated at $27.4 \%$. It is noteworthy to point out, however, that even though the researchers employ the same formula to estimate the initial return, the composition of the 
samples can vary. The results of studies into underpricing in the WSE in the years 1991-1998 are presented in Table 3.

Table 3. Average initial return in Poland

\begin{tabular}{|c|c|c|c|c|}
\hline Country & Time period & Sample size & $\begin{array}{c}\text { Average initial } \\
\text { return (\%) }\end{array}$ & Researchers \\
\hline Poland & $1991-1998$ & 140 & 27.4 & Jelic and Briston \\
\hline Poland & $1991-1998$ & 103 & 54.5 & Lyn and Zychowicz \\
\hline Poland & $1991-1998$ & 149 & 35.6 & Aussenegg \\
\hline
\end{tabular}

Source: own study based on: Ritter (2003), pp. 421-434; Aminul, Ruhani, Zamri (2010), pp. 36-46; Gounopoulos, Nounis, Stylianides (2007), pp. 1-25.

The case of Poland shows that the different studies conducted by various research teams who investigated companies entering the market in the years 1991-1998 (yet used different samples) generated entirely different results.

At present, companies in Poland may raise capital in either the WSE or the alternative New Connect platform. The latter was established in 2007 and is an unregulated market targeted at small, innovative, dynamic and risky companies. The main market, the WSE was established in 1991. It is a regulated market which lists more than 400 companies from Poland and other countries. The total WSE capitalisation is estimated at approx. EUR 140 billion, which is $7-15$ times less than the major European stock exchanges such as LSE, BME, NYSE Euronext or Deutsche Börse. Despite its lower capitalisation, in 2010 the Polish stock exchange grew much more dynamically than other markets in the region. The Polish stock exchange as a whole (i.e. both the WSE and NC) witnessed 112 IPOs worth EUR 3.81 billion in total. It was the second highest value in Europe, lower only than that of the London Stock Exchange which recorded 114 IPOs at the total value of EUR 10.52 billion. Also in 2009 the Polish stock exchange belonged to the top three stock exchanges in Europe in terms of both the number of IPOs and their total values ${ }^{4}$.

\section{The origins of IPO underpricing versus the January effect}

As soon as IPO underpricing was identified, the researchers made attempts to provide its explanation. As a result, a variety of concepts and theories explaining this phenomenon were developed. The concepts can be grouped depending on whether they are related to the information asymmetry, ownership and control, behavioural finance and institutional explanations. One of these theories, perhaps the best-known, is “the winner's curse hypothesis" developed and 
published by Rock ${ }^{4}$. This theory belongs to the group of explanations deriving from the theory of information asymmetry. Information asymmetry in economics describes a situation when one of the parties involved in a transaction is better informed than the other party. It usually implies that the seller is better informed than the buyer. The party which has access to all the available information and is better informed is known as the agent. The other, less informed, party which does not have access to all the information is known as the principal, and has to rely on the better-informed party while making decisions. "The winner's curse hypothesis" assumes that there are two types of investors - well-informed and underinformed. Investors will invest in shares of a company only if their price is lower than the company's fair value. If, however, the price is above the fair value, only underinformed investors will buy the shares. As a result, the demand for the shares will be lower than it would be if both groups of investors were interested in buying them, so it is more probable that the shares will yield a negative return on the first day of trade. Uninformed investors, however, are aware of this fact and will buy the shares only if the expected return on investment is positive. As a consequence, the issuers need to underprice the shares offered so as to attract uninformed investors. Apart from this theory there are many others which attempt to explain underpricing based on the information asymmetry and those include: "The costly information acquisition hypothesis" developed by Benveniste and Spindt in 1989, "The investment banker's monopsony power hypothesis" proposed by Baron in 1982, "The signalling hypothesis" developed in 1989 by Allen and Faulhaber, Welch, Grinblatt and Hwang. All the theories in this group assume the existence of two parties involved, with one of them being more informed (the agent) than the other (the principal) 6 .

The group of concepts and theories offering institutional explanations is based mostly on legal aspects concerning regulations in selected markets as well as changes which have been introduced in the law regulating trade in capital markets. One of the concepts in this group is the lawsuit avoidance concept, proposed by Tinic in 1988. According to this concept, issuers underprice their shares since they want to protect themselves from being sued by investors in relation to their IPOs. In the United States the right to lawsuits is regulated by the Securities Act of 1933. The US Securities and Exchange Commission imposed an obligation of due-diligence on institutions introducing a company to the market so as to minimise the risk of errors and misleading information. This act enabled litigation against underwriters. According to this concept, underwriters, to protect from excess number of lawsuits ruining their reputation may lower the price set by the issuer so as to give the investors no reasons for litigation. Tinic argues that the less prestigious the underwriter, the higher the probability they will be sued, as they are not able to assure proper quality of due-diligence ${ }^{7}$. Institutional explanations include also 
“The institutional lag hypothesis" proposed by Ritter in 1984, the minimum tax concept developed originally by Dandapani, Dossani, Prakash and Reside in 1992, "The market incompleteness hypothesis" proposed in 1992 by Mauer and Spindt and the price stabilisation concept proposed by Ruud in $1993^{8}$. All these concepts explain underpricing with legal regulations and the structure of the capital market. It is noteworthy to observe, however, that each country has its specific legal framework and structure of the market, so the explanations from this field may only be considered as complementary to other explanations for underpricing.

Another group of explanations covers those related to ownership and control. In many cases the entrance to the capital market is a step towards separation of ownership and control. As a consequence of such separation, it is managers rather than owners who make operational and investment decisions. This separation leads to agency problems where owners and managers have different individual objectives. Owners are concentrated on value maximisation while managers strive for maximising their own benefits, which not necessarily overlap with the maximisation of the company value. Two contradictory concepts originated as a result. One of them assumes the underpricing of IPO so as to disperse shareholders and ensure that the company is controlled by the present managers. The second concept assumes the reduction of agency costs through assigning a block of shares to an external investor; that block of shares is large enough to enable control over the costs of managers yet small enough to avoid affecting the full control. This suboptimal, from the viewpoint of investors, block of shares needs to be underpriced as a way to attract an investor. The first concept, known as the Underpricing as a Means to Retain Control, was introduced by Brennan and Franks in 1995 . The second concept, the Underpricing as a Means to Reduce Agency Costs was developed by Stoughton and Zechner who proposed it in $1998^{10}$.

There are also explanations for IPO underpricing which derive from behavioural finance. This area of the science of finance incorporates the psychological, social and anthropological dimension into analyses of financial market behaviours. The definitions within behavioural finance coined by individual researchers focus on the psychological aspect of the human nature, investor and market player $^{11}$. One of the variety of hypotheses explaining IPO underpricing which derives from behavioural finance is the "Cascades hypothesis" proposed by Welch in $1992^{12}$. In his model potential investors take into account not only the information at their disposal but also the information possessed by other investors. And so, if an investor observes other investors' interest in purchasing certain shares, he or she also becomes more interested in those shares. On the other hand, if an investor perceives no interest in certain shares, he or she also withdraws from purchasing them even in spite of favourable information from the 
company. Issuers may underprice their shares so as to encourage first investors to purchase shares and initiate the cascade effect. As a consequence, next investors, who observe interest in the company, may deduce that if other investors want to purchase shares, they must have had access to favourable information on the company and hence their interest in those shares. The Prospect Theory proposed by J.R. Ritter and T. Loughran in 2002 is also one of the theories which attempt to provide explanation for the IPO underpricing based on behavioural finance.

Stock exchanges are affected by various anomalies, understood as deviations from normal distributions of returns, some of them known together as calendar effects. Those effects may exert an influence on the scale of IPO underpricing. One the best-known in the group of calendar effects is the January effect. It refers to the fact that listed companies yield higher returns in January than in other months. Kinney and Rozeff observed in 1976 that the average return in the NYSE in January was indeed higher than returns in other months. In 1983 Keim observed that the January effect was particularly significant in the case of companies with small capitalisation $^{13}$.

The occurrence of the January effect is explained with the "tax loss selling hypothesis". The hypothesis assumes that at the year's end investors sell their shares which yielded losses so as to take advantage of tax benefits while at the beginning of January they repurchase those shares thus driving their prices up. This mechanism is known as the January effect. Another explanation of the January effect is the assumption that professionals who manage portfolios on behalf of their clients are obliged to disclose to them the composition of those portfolios at the end of the year. As a consequence, they sell shares of small unprofitable companies yielding losses only to repurchase them at the beginning of January thus driving their market value. Yet another explanation of the January effect is related to the inflow of positive information to the market, when at the beginning of the year companies announce their new development plans, restructuring plans and optimistic outlooks for the next year ${ }^{14}$. Another attempt to explain the January effect refers to the remuneration system for portfolio management. The earnings of managers are related to the return on the market index, which is then compared and contrasted to the return on the portfolio at the year-end. In the new year the managers start to reconstruct portfolios thus driving the demand and share prices up ${ }^{15}$.

\section{Hypothesis, data and methodology}

The January effect, which is induced by increased demand for stock, should also exert an influence on the scale of IPO underpricing. If such an impact can be observed, it will imply 
that investors should be more willing to buy the shares of companies entering the stock market in January rather than in other months. It means also that the initial return on the stock of companies offering their shares in January should be on average higher than the initial returns for other months. The following hypothesis can, therefore, be formulated:

$\mathrm{H}_{0}$ : The initial return on IPOs taking place in January is equal to the initial return on IPOs in other months.

$\mathrm{H}_{1}$ : The initial return on IPOs taking place in January is higher than the initial return on IPOs in other months.

In the years 2005-2011, 272 companies in total entered the Warsaw Stock Exchange. 11 of them transferred to the WSE from the CeTO ${ }^{16}$ market, 15 transferred from the New Connect market, 22 were listed on at least two markets (dual listing), and 8 decided to enter the WSE without offering their shares. All these companies were excluded from the study, and as a result the final sample comprised 216 companies. Otherwise, an analysis of initial returns for companies which had been previously valued by investors on a different market or did not offer their shares at all would have distorted the results. As a result, these companies were excluded from the sample. The number of companies which comprised the sample as well as the number of IPOs are provided in Table 4.

Table 4. Number of IPOs on the Warsaw Stock Exchange in years 2005-2011

\begin{tabular}{|c|c|c|c|c|}
\hline \multirow{2}{*}{ Year } & Number of IPOs & \multicolumn{3}{|c|}{ Number of IPOs covered by the research } \\
\cline { 3 - 5 } & on WSE & January & other months & sum \\
\hline 2005 & 35 & 3 & 30 & 33 \\
\hline 2006 & 38 & 0 & 36 & 36 \\
\hline 2007 & 81 & 3 & 59 & 62 \\
\hline 2008 & 33 & 0 & 23 & 23 \\
\hline 2009 & 13 & 1 & 11 & 12 \\
\hline 2010 & 34 & 0 & 23 & 23 \\
\hline 2011 & 38 & 2 & 25 & 27 \\
\hline Sum & 272 & 9 & 207 & 216 \\
\hline
\end{tabular}

Source: own study based on: WSE (2012).

IPO underpricing is estimated with the initial return $\left(I_{n}\right)$ based on closing prices:

$$
I_{n}=\frac{\left(P_{d}-P_{e}\right)}{P_{e}} \cdot 100 \%
$$

Sometimes the stock is offered at different prices for individual and institutional investors. In this study the offering price $\left(P_{e}\right)$ is defined as the offering price set for individual investors. 
The closing price $\left(P_{d}\right)$ is the price of either the shares or - in the case of lack thereof - the rights to shares reported at the closing of the first-day trade session. Verification of the $\mathrm{H}_{0}$ hypothesis was based on the t-test according to the following formula:

$$
T=\frac{\bar{x}_{1}-\bar{x}_{2}}{\sqrt{\frac{n_{1} \cdot S_{1}{ }^{2}+n_{2} \cdot S_{2}{ }^{2}}{n_{1}+n_{2}-2} \cdot\left(\frac{1}{n_{1}}+\frac{1}{n_{2}}\right)}}
$$

where:

$\bar{x}_{1}, S_{1}, n_{1}$ - arithmetic mean, standard deviation and size of the first sample,

$\bar{x}_{2}, S_{2}, n_{2}$ - arithmetic mean, standard deviation and size of the second sample.

The critical area of the null hypothesis was based on the $t_{\alpha}$ critical value depending on the alternative hypothesis and the significance level. If the absolute value of the t-statistic is higher than or equal $\mathrm{t}_{\alpha}$ then $\mathrm{T}$ belongs to the critical area and the null hypothesis should be rejected in favour of the alternative hypothesis, and the probability of type I error, i.e. that the null hypothesis is true, is equal to the $\alpha$ significance level ${ }^{17}$.

\section{Results}

IPO underpricing, which was observed for various periods in all the analysed markets across the world, was witnessed also on the Warsaw Stock Exchange in the years 2005-2011. The characteristics describing the phenomenon by individual years are summarised in Table 5 .

Table 5. Initial return in the Warsaw Stock Exchange in the years 2005-2011

\begin{tabular}{|c|c|c|c|}
\hline Year & $\begin{array}{c}\text { Median } \\
(\%)\end{array}$ & $\begin{array}{c}\text { Average } \\
(\%)\end{array}$ & Standard deviation \\
\hline 2005 & 4.30 & 9.48 & 0.1895 \\
\hline 2006 & 10.83 & 34.48 & 0.8158 \\
\hline 2007 & 11.27 & 16.53 & 0.2856 \\
\hline 2008 & -0.97 & 1.41 & 0.1274 \\
\hline 2009 & 11.92 & 14.51 & 0.1153 \\
\hline 2010 & 3.86 & 5.17 & 0.0858 \\
\hline 2011 & 2.05 & 1.13 & 0.1071 \\
\hline Whole period & 5.26 & 13.59 & 0.3957 \\
\hline
\end{tabular}

Source: own study based on: WSE (2012). 
The highest IPO underpricing was reported in 2006. It was influenced mostly by the Inwest Consulting company, which went public in July 2006. The offering price was set at PLN 3.75 per share, and the first-day closing price was nearly 5-fold higher - at PLN 21.8 per share. If we exclude this company, the average IPO underpricing in 2006 amounts to $21.72 \%$. Apart from 2006, high average underpricing was also reported in 2007 which witnessed the greatest number of IPOs in the entire period, and in 2009, when the number of IPOs was the smallest. In each of the three years the average IPO underpricing measured with median oscillated around $11-12 \%$ and the mean underpricing exceeded 14\%. The lowest IPO underpricing was witnessed in 2008 and 2011, with means not exceeding 1.5\%. In 2008, for more than 50\% of companies entering the WSE the offering prices were found to be higher than their first-day closing prices, which means that the shares offered were overpriced. It is noteworthy to point out that in 2008 the WSE suffered from severe declines. The main index, WIG20, lost nearly $50 \%$ between 1 January 2008 and 31 December 2009, which affected the initial returns on IPOs. Number of issuers covered by research debuting in different months is presented on Figure 1.

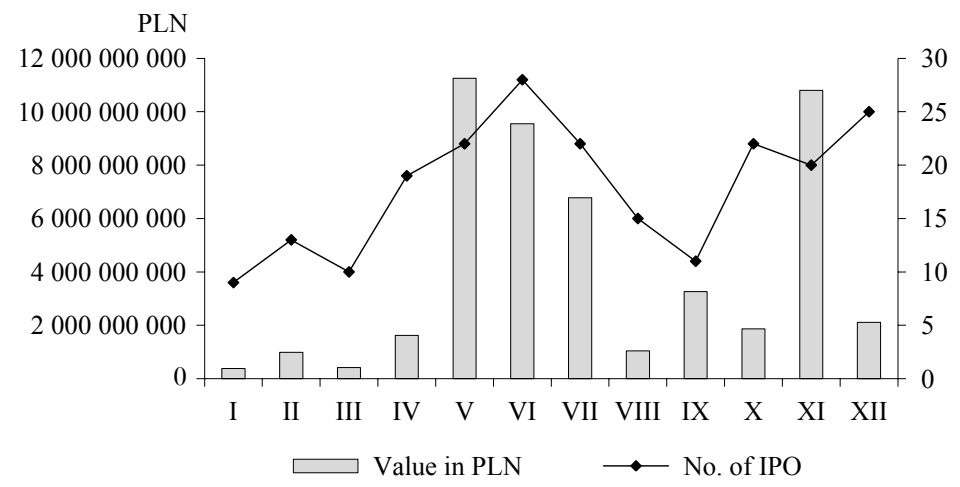

Fig. 1. Number of Issuers debuting on the WSE in years 2005-2011 in different months Source: own study based on: WSE (2012).

During years 2005-2011 in January number and value of IPOs was the lowest. The results of the research into underpricing according to the month of the offer are summarised in Table 6 . 
Table 6. Initial return from IPOs on the WSE in years 2005-2011 in according to the month of the offer

\begin{tabular}{|c|c|c|c|c|c|c|c|c|}
\hline \multirow{2}{*}{ Month } & \multirow{2}{*}{$\begin{array}{l}\text { No. } \\
\text { of IPOs }\end{array}$} & Min & Q1 & Median & Q3 & Max & Average & \multirow{2}{*}{ Std Dev } \\
\hline & & \multicolumn{6}{|c|}{$\%$} & \\
\hline I & 9 & -0.63 & 14.67 & 28.55 & 33.16 & 64.50 & 26.75 & 0.178 \\
\hline II & 13 & -6.33 & 5.00 & 6.11 & 15.71 & 34.05 & 9.19 & 0.099 \\
\hline III & 10 & -8.93 & -3.00 & 10.32 & 17.58 & 30.00 & 8.68 & 0.122 \\
\hline IV & 19 & -11.54 & -0.61 & 5.44 & 16.87 & 69.44 & 10.37 & 0.181 \\
\hline $\mathrm{V}$ & 22 & -21.91 & 0.14 & 5.09 & 16.85 & 83.00 & 14.09 & 0.258 \\
\hline VI & 28 & -19.74 & -1.70 & 0.16 & 5.34 & 30.00 & 1.75 & 0.099 \\
\hline VII & 22 & -1.67 & 3.95 & 8.20 & 20.27 & 481.33 & 41.62 & 1.022 \\
\hline VIII & 15 & -13.36 & -1.93 & 1.22 & 16.90 & 55.00 & 7.52 & 0.171 \\
\hline IX & 11 & -19.12 & 0.58 & 3.23 & 11.53 & 27.85 & 5.53 & 0.114 \\
\hline $\mathrm{X}$ & 22 & -24.67 & -1.99 & 4.53 & 14.07 & 100.00 & 9.85 & 0.247 \\
\hline $\mathrm{XI}$ & 20 & -17.50 & -0.90 & 1.29 & 15.04 & 125.56 & 15.22 & 0.347 \\
\hline XII & 25 & -11.84 & 0.65 & 7.59 & 15.08 & 87.86 & 12.85 & 0.205 \\
\hline Sum & 216 & -24.67 & -0.19 & 5.26 & 16.19 & 481.33 & 13.59 & 0.396 \\
\hline
\end{tabular}

Source: own study based on: WSE (2012).

Comparing to other months the highest median and second highest average underpricing occurred in January. The lowest median and average underpricing occurred in June. Summarised results of the research into underpricing in January and other months in years 2005-2011 are presented in Table 7.

Table 7. Initial return from IPOs on the WSE in years 2005-2011 in January and other months

\begin{tabular}{|c|c|c|c|c|c|c|}
\hline \multirow{3}{*}{ Year } & \multicolumn{3}{|c|}{ Initial return from IPOs in January } & \multicolumn{3}{|c|}{ Initial return IPOs in February - December } \\
\hline & median & average & \multirow{2}{*}{$\begin{array}{l}\text { standard } \\
\text { deviation }\end{array}$} & median & average & \multirow{2}{*}{$\begin{array}{l}\text { standard } \\
\text { deviation }\end{array}$} \\
\hline & \multicolumn{2}{|c|}{$\%$} & & \multicolumn{2}{|c|}{$\%$} & \\
\hline 2005 & 16.19 & 21.14 & 0.0811 & 4.04 & 8.31 & 0.1932 \\
\hline 2006 & - & - & - & 10.83 & 34.48 & 0.8158 \\
\hline 2007 & 33.16 & 36.84 & 0.2124 & 10.00 & 15.50 & 0.2850 \\
\hline 2008 & - & - & - & -0.97 & 1.41 & 0.1274 \\
\hline 2009 & 38.90 & 38.90 & 0.0000 & 10.83 & 12.29 & 0.0927 \\
\hline 2010 & - & - & - & 3.86 & 5.17 & 0.0858 \\
\hline 2011 & 13.96 & 13.96 & 0.1459 & 2.05 & 0.11 & 0.0963 \\
\hline $\begin{array}{l}\text { Whole } \\
\text { period }\end{array}$ & 28.55 & 26.75 & 0.1780 & 5.06 & 13.01 & 0.4015 \\
\hline
\end{tabular}

Source: own study based on: WSE (2012).

In the years 2005-2011 only 9 companies chose to enter the market in January. The other 207 companies went public between February and December. In the entire period as a whole as 
well as in individual years the average and mean IPO underpricing in January was higher than in the case of companies going public in other months. The average underpricing of January IPOs amounted to $26.75 \%$ for the entire period at a standard deviation of $17.8 \%$. For the remaining IPOs, the two figures reached $13.01 \%$ and $40.15 \%$, respectively.

The $\mathrm{t}$ statistic estimated according to the above formula equals 1.0172 , which is higher than $\mathrm{t}_{\alpha}$, i.e. 2.61 at the $\alpha=0.01$ significance level. As a consequence, based on the evidence from the research, the $\mathrm{H}_{0}$ hypothesis cannot be rejected, which means that it is impossible to confirm the impact of the January effect on the IPO underpricing in the WSE in the years 2005-2011. Despite higher average underpricing reported for IPOs in January as compared and contrasted to other months, the results of the research are not statistically significant.

\section{Conclusions}

Recently the Polish capital market has belonged to the top three European stock markets in terms of the number of IPOs. For every year between 2005 and 2011 Poland witnessed the occurrence of the underpricing phenomenon at the average annual level of $13.59 \%$. In earlier studies, carried out between 1991 and 1998, the average IPO underpricing ranged from $27 \%$ to $54 \%$, depending on the sample. At present the companies "leave less money on the table" than they used to in the past. IPO underpricing, just as the calendar effects, belongs to the anomalies observed in the capital market. There are a variety of concepts and empirical studies which attempt to explain IPO underpricing. The paper concentrates on the impact of the January effect on the IPO underpricing. The authors analysed 216 companies which went public in the years 2005-2011 on the WSE. Companies which had already been listed on another stock exchange and companies which went public without offering their shares were excluded from the sample. Between 2005 and 2011 only 9 companies in the sample chose to enter the market in January; January was selected as a month of IPO by approximately two times less companies than any other month. The average IPO underpricing among companies which went public in January both in every year separately and throughout the entire period as a whole was higher than the average IPO underpricing observed for other months. The results of the study are not statistically significant. The IPO underpricing in the period of analysis could have been influenced by the crisis of 2008 when the average IPO underpricing was hardly observed at all.

Co-author Adrian Woloszyn is a scholarship-holder in the framework of Submeasure 8.2.2 "Regional Innovation Strategies", Measure 8.2 "Knowledge Transfer", Priority VIII "Regional Human Resources for Economy” Operational Programme Human Capital. The scholarship was 
co-funded by the EU European Social Fund, the state budget and the budget of the Lubuskie province.

\section{Notes}

1 Ritter (1984), pp. 215-240.

2 Securities and Exchange Comission (1963).

${ }^{3}$ Chambers, Dimson (2009), pp. 2-43.

4 PwC (2010), pp. 1-22.

5 Rock (1986), pp. 187-212.

${ }^{6}$ Ibbotson, Ritter (1995), pp. 993-1016.

7 Tinic (1988), pp. 789-822.

8 Ljungqvist (2004), pp. 1-67.

9 Brennan, Franks (1997), pp. 391-413.

${ }^{10}$ Ljungqvist (2004), pp. 1-67.

11 Tyszka (2003).

${ }^{12}$ Welch (1992), pp. 695-732.

13 Ślepczuk (2012).

${ }^{14}$ Gabryś (2006).

15 Szyszka (2000), pp. 1-18.

${ }^{16}$ CeTO was one of the markets in Poland where companies were able to raise capital.

${ }^{17}$ Hozer (1994).

\section{References}

Aminul, I., Ruhani, A. \& Zamri, A. (2010). Underpricing of IPOs: The Case of Bangladesh. Global Economy and Finance Journal, Vol. 3, No. 1.

Brennan, M. \& Franks, J. (1997). Underpricing, ownership and control in initial public offerings of equity securities in the UK. Journal of Financial Economics, 45.

Chambers, D. \& Dimson, E. (2009). IPO Underpricing Over the Very Long Run. Journal of Finance, Vol. 64, No. 3.

Gabryś, A. (2006). Efektywność rynku kapitałowego: poszukiwania teoretyczn i obserwacje empiryczne, www.aureamediocritas.pl (30.12.2012).

Gounopoulos, D., Nounis, C. \& Stylianides, P. (2007). The Short and Long Term Peformance of Initial Public Offerings in the Cyprus Stock Exchange. Journal of Financial Decision Making, Vol. 4, No. 1. 
Hozer, J. (1994). Statystyka część II wnioskowanie statystyczne skrypt dla studentów kierunków ekonomicznych. Szczecin: Wydawnictwo Naukowe Uniwersytetu Szczecińskiego.

Ibbotson, R. \& Ritter, J. (1995). Initial Public Offerings. In: R. Jarrow et al., Handbooks in OR \& MS, Vol. 9.

Ljungqvist, A. (2004). IPO Underpricing. In: B.E. Eckbo, Handbook in Corporate Finance: Empirical Corporate Finance.

Loughran, T., Ritter, J. \& Rydqvist, K. (2010). Initial Public Offerings: International Insights, http://bear.warrington.ufl.edu (21.12.2012).

PwC (2012). IPO Watch Europe - 2010, www.pwc.com (30.11.2012).

Ritter, J. (1984). The "Hot Issue" Market of 1980. The Journal of Business, Vol. 57, No. 2.

Ritter, J. (2003). Differences between European and American IPO Markets. European Financial Management.

Rock, K. (1986). Why new issues are underpriced? Journal of Financial Economics, Vol. 15.

Securities and Exchange Comission (1963). Report of special study on security markets. Washington: U.S. Government Printing Office.

Szyszka, A. (2000). Efektywność rynku kapitałowego a anomalie rozkładu stóp zwrotu w czasie, http://atinvest.pl.

Ślepczuk, R. (2012). Anomalie rynku kapitałowego w świetle hipotezy efektywności rynku, www.skarbiec.biz (21.12.2012).

Tinic, S. (1988). Anatomy of Initial Public Offerings of Common Stock. Journal of Finance, 43.

Tyszka, T. (2003). Psychologia ekonomiczna. Gdańsk: GWP.

Welch, I. (1992). Sequential Sales Learning and Cascades. The Journal of Finance, Vol. 47, No. 2.

WSE (2012). Podstawowe Statystyki GPW, www.gpw.pl (30.12.2012). 